\title{
Health Risk Assessment Due to Heavy Metals Exposure via Consumption of Bivalves Harvested from Marudu Bay, Malaysia
}

\author{
Delta Jenetty Denil, Ching Fui Fui, Julian Ransangan \\ Borneo Marine Research Institute, University Malaysia Sabah, Kota Kinabalu, Malaysia \\ Email: liandra@ums.edu.my
}

How to cite this paper: Denil, D.J., Fui, C.F. and Ransangan, J. (2017) Health Risk Assessment Due to Heavy Metals Exposure via Consumption of Bivalves Harvested from Marudu Bay, Malaysia. Open Journal of Marine Science, 7, 494-510. https://doi.org/10.4236/ojms.2017.74035

Received: July 12, 2017

Accepted: October 17, 2017

Published: October 20, 2017

Copyright $\odot 2017$ by authors and Scientific Research Publishing Inc. This work is licensed under the Creative Commons Attribution International License (CC BY 4.0).

http://creativecommons.org/licenses/by/4.0/

\section{(c) () Open Access}

\begin{abstract}
Concern over health risk from consumption of bivalves originating from Marudu Bay is escalating due to the rapid agricultural development surrounding the bay. This has motivated us to estimate the health risk index (HRI) of heavy metals from four commercially important and highly exploited bivalve species which are abundant in the bay. Samples $(n=30)$ of green mussel (Perna viridis), Asiatic hard clam (Meretrix meretrix), Pacific oyster (Crassosstrea gigas) and marsh clam (Polymesoda expansa) were acquired from fishermen in Kg. Teritipan, Marudu Bay. These bivalves were analyzed for heavy metals content using the Inductively Couples Plasma-Optical Emission Spectroscopy (ICP-OES). The study found that the mean contents of Arsenic (As) and Manganese ( $\mathrm{Mn})$ in all analyzed bivalves exceeded the permissible limits as well as copper $(\mathrm{Cu})$, lead $(\mathrm{Pb})$ and zinc $(\mathrm{Zn})$ in Pacific oyster, and $\mathrm{Zn}$ in marsh clam. It was also noticed that consumption of different bivalve species may bring about health risk from different metals as indicated by varied Total Hazard Index (THI) values. Consumption of the four bivalves was noticed to promote high health risk from As intoxication. Although metal pollution index (MPI) analysis revealed that the bivalves from the bay are currently not seriously impacted by heavy metal pollution, vigorous efforts should be taken to preserve the natural condition of the bay for years to come. There are several ways to minimize health issues from bivalve consumption which include keeping the bivalve natural habitat away from heavy metals pollution by strictly enforcing environmental laws and policies, establishing zones for bivalve fisheries, monitoring heavy metals concentration in bivalve on a regular basis and making depuration process a compulsory requirement in every seafood restaurant throughout the country.
\end{abstract}

\section{Keywords}

Health Risk Assessment, Heavy Metal, Bivalves, Marudu Bay 


\section{Introduction}

Health risk assessment on heavy metals is usually carried out to assess the total exposure of heavy metals among the population in a particular place. It helps to formulate preventive measures in order to take care of the public health [1] [2] [3]. Many health risk assessments have been conducted on bivalves due to its high adaptability to various levels of contaminations [4]. Despite being a good source of low-cost protein, accumulated heavy metals in bivalves can cause major concern to consumer's health. One of the prominent sites for bivalve fishing in Sabah is Marudu Bay. The bay is located in Kota Marudu district on the northern part of Malaysian Borneo and included in the Tun Mustapha Marine Park, the largest marine protected area within the Malaysian Coral Triangle region. The bay has been known to house at least 22 species of invertebrate fauna including bivalves [5]. In fact, the bay has been alienated for bivalve aquaculture development zone by the Fisheries Department of Sabah.

However, a study by [6] revealed that the farmed green mussel in the bay contained manganese $(\mathrm{Mn})$ that exceeds the permissible limit of $5.4 \mathrm{mg} / \mathrm{kg}$ [7]. Although previous study by [8] concluded that the heavy metal level in Marudu Bay was still within the permissible limit, the same study, however, reported high content of $\mathrm{Mn}$ in the surface sediment of the bay. Perhaps, one of the possible reasons for this situation is the rapid coastal development around the bay especially human settlement and oil palm plantation.

The ability to identify the sources of heavy metal pollutant is useless without measuring its effects to human health. Hence, health risk assessment is required in order to determine the probability of human health risk due to heavy metals following the consumption of bivalves originating from a collection site. To the best of our knowledge, green-lipped mussel (Perna viridis), Asiatic hard clam (Meretrix meretrix), Pacific oyster (Crassosstrea gigas) and marsh clam (Polymesoda expansa) are the most commercially exploited bivalve species in Marudu Bay. In this paper we estimated the health risk index (HRI) due to heavy metals in relation to the consumption of these bivalve species originating from the bay.

\section{Materials and Methods}

\subsection{Sample Collection}

A total of 30 specimens of each bivalve species including green-lipped mussel ( $P$. viridis), Asiatic hard clam (M. meretrix), Pacific oyster ( $C$. gigas) and marsh clam ( $P$. expansa) were acquired from fishermen who harvest different species of bivalves in the Marudu Bay (Figure 1). The specimens were transported to the laboratory in polystyrene box containing ice cubes. The specimens were then dissected by using acid washed stainless steel knife. The whole soft tissues were kept in zip-lock bag then stored in $-80^{\circ} \mathrm{C}$ ultralow freezer (U570-86, New Brunswick). Prior to further analyses, the specimens were oven-dried at $105^{\circ} \mathrm{C}$ for 24 hours [9]. Then grounded to powder using mortar and pestle, and kept in zip-lock bags until analysis. 


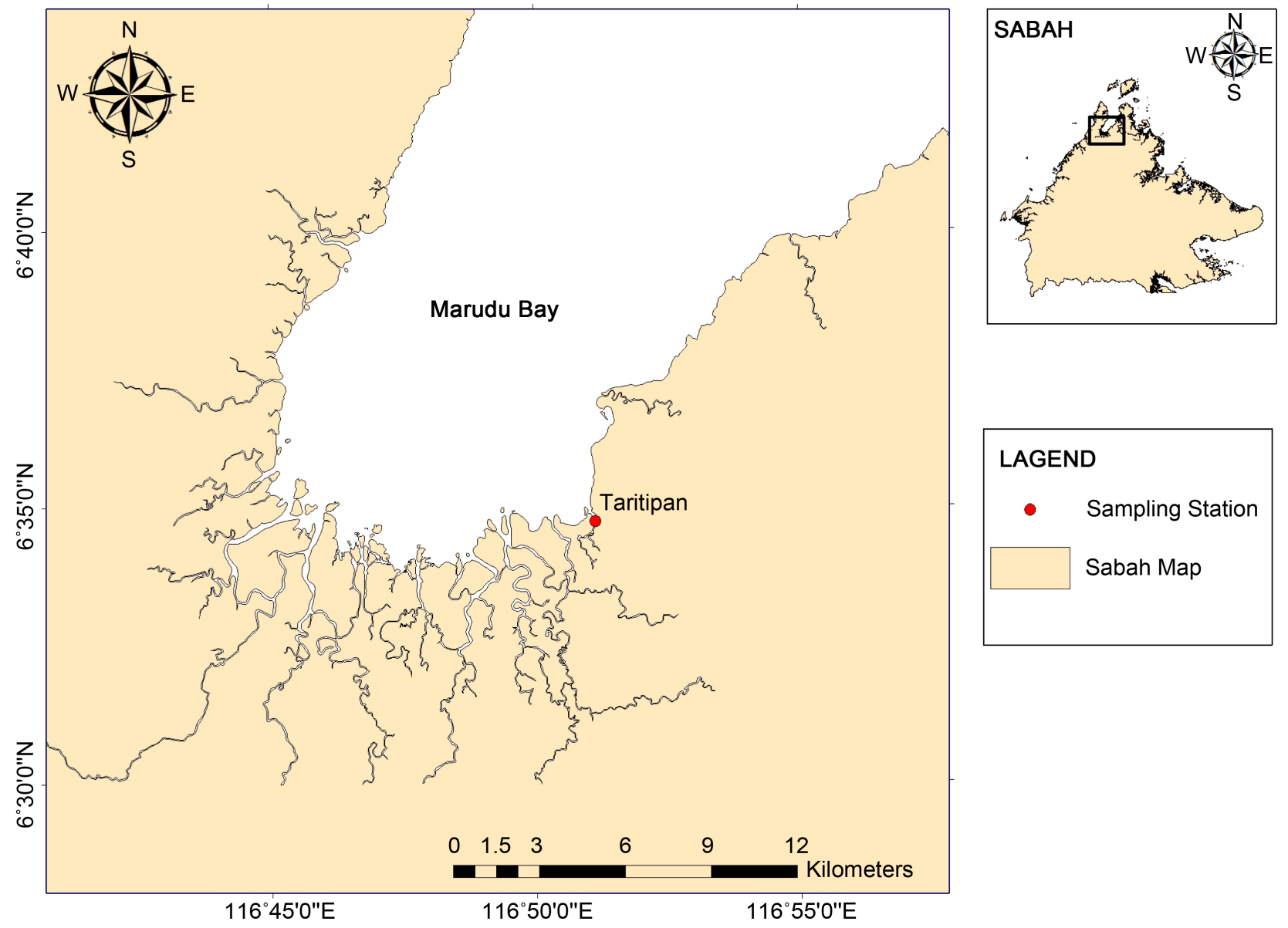

Figure 1. Sampling area.

\subsection{Sample Digestion}

Sample digestion was carried out in hot block digester (Tecator Digestor Auto 8, FOSS) according to the method described by [10]. Prior to digestion, all glassware were first rinsed with $1 \mathrm{~N}$ nitric acid. Then, $0.5 \mathrm{~g}$ of powdered sample was weighed using electronic balance (Pecisa 404A) and placed in digesting tubes. 15 $\mathrm{ml}$ of $65 \%$ nitric acid (Merck) and $2.5 \mathrm{ml}$ of $70 \%-72 \%$ perchloric acid (Merck) were added in the tubes. The tubes were heated at $140^{\circ} \mathrm{C}$ for 10 minutes in hot block digester. Then, $5 \mathrm{ml}$ of $37 \%$ hydrochloric acid (AR Grade, Qrec) was added in the tubes. Subsequently, the temperature was raised to $200^{\circ} \mathrm{C}$ and digestion process proceeded for 3 hours. When digestion completed, the tubes were left to cool at room temperature before adding $1.25 \mathrm{ml}$ of $65 \%$ nitric acid and $10 \mathrm{ml}$ of double distilled water. The solution was filtered using Whatman filter paper (No. 1001-110) and top-up to $35 \mathrm{ml}$ with double distilled water. Finally, the filtrates were kept in $20 \mathrm{ml}$ glass vials and stored at $4^{\circ} \mathrm{C}$ until heavy metal analysis.

\subsection{Heavy Metal Determination}

Heavy metal content in the bivalve samples was determined by using the Inductively Couples Plasma-Optical Emission Spectroscopy (ICP-OES), Perkin Elmer 
Optima 5300DV. Quality Control Standard 21 (Perkin Elmer Pure) was used as Standard Reference Material (SRM1646a) for instrument recovery. Triplicate readings were obtained for every sample. Assessment of measurement quality and precision was achieved by running blank samples and certified standard materials Dogfish liver DOLT-5 (National Research Council Canada) alongside with the bivalve samples.

\subsection{Health Risk Assessment}

Health risk assessment was carried out by calculating the Hazard Quotient (HQ) according to [4] and [11] (Table 1). Health risk assessment of the toxicants was interpreted based on the values of HQ and Total Hazard Index (THI) [12].

$$
\mathrm{HQ}=\frac{(\mathrm{EF})(\mathrm{ED})(\mathrm{IR})(\mathrm{C})}{(\mathrm{RFD})(\mathrm{WAB})(\mathrm{TA})}
$$

The THI is the sum of HQ of respective heavy metal in the sample. Where, $\mathrm{HQ}_{n}$ is the hazard quotient for metal $n$ in the sample.

$$
\mathrm{THI}=\sum \mathrm{HQ}=\mathrm{HQ}_{1}+\mathrm{HQ}_{2}+\mathrm{HQ}_{3}+\cdots+\mathrm{HQ}_{n}
$$

Values of HQ and THI below 1.0 indicate no risk of adverse health effect and the greater the value, the greater the risk level of the heavy metal intoxication [12].

\subsection{Metal Pollution Index}

To compare the heavy metal contents in different bivalves, metal pollution index was calculated by using the following formula [15].

$$
\mathrm{MPI}=\left(\mathrm{Cf}_{1}, \mathrm{Cf}_{2}, \cdots, \mathrm{Cf}_{n}\right)^{1 / n}
$$

where $\mathrm{Cf}_{n}$ is the concentration of the metal $n$ in the sample. The MPI index value was adapted from [2] as shown in Table 2.

\subsection{Statistical Analysis}

The SPSS Windows Statistical Package (version 22.0) was used for all statistical analyses. All data were subjected to one-way ANOVA with all variables tested for normality and homogeneity of variances. Significance level was set at $\mathrm{p}<$

Table 1. Values used to calculate Hazard Quotient (HQ).

\begin{tabular}{cc}
\hline & Unit \\
\hline EF, exposure frequency & days/year \\
ED, exposure duration & years \\
IR, ingestion rate & $0.082 \mathrm{~kg} /$ day $/$ person, $[13]$ \\
C, metal content in edible part & $\mathrm{mg} / \mathrm{kg}$ \\
RFD, oral reference dose, & $\mathrm{mg} / \mathrm{kg} / \mathrm{day}$ \\
WAB, average body weight & $62.6 \mathrm{~kg},[14]$ \\
TA, average exposure & 365 days $/$ year x ED \\
\hline
\end{tabular}


Table 2. MPI index value adapted from [2].

\begin{tabular}{cc}
\hline Index Value & Degree of Pollution \\
\hline MPI $>2$ & Not impacted \\
$2<$ MPI $<5$ & Very low contamination \\
$5<\mathrm{MPI}<10$ & Low contamination \\
$10<\mathrm{MPI}<20$ & Medium contamination \\
$20<\mathrm{MPI}<50$ & High contamination \\
$50<\mathrm{MPI}<100$ & Very high contamination \\
$\mathrm{MPI}>100$ & Extreme contamination \\
\hline
\end{tabular}

0.05. One-way ANOVA was performed and followed by the Tukey multiple comparison test (Tukey HSD) to make specific contrast of heavy metals content in the bivalves. A multivariate analysis (Principal component analysis) was performed to highlight the relationship between heavy metals. Varimax rotation was performed to help interpret the principal components.

\section{Results}

\subsection{Heavy Metals Content in Bivalves}

The heavy metals contents in the four bivalve species collected from Marudu Bay are as shown in Table 3. It was noted that the As and Mn contents in all species of bivalves exceeded the permissible limits. The same was noticed to $\mathrm{Cu}, \mathrm{Pb}$ and $\mathrm{Zn}$ in Pacific oyster and $\mathrm{Zn}$ in marsh clam (Table 3).

\subsection{Health Risk Assessment of Bivalves}

Hazard Quotient (HQ) exceeding 1.0 is considered threatening human health [1]. In this study, HQ for Fe andLi was not calculated because its oral reference dose and permissible limits have not been specified by any international standard providers. The calculated HQ of heavy metals in the four bivalve species is given in Table 4. Based on the HQ cut-point, it showed that all four bivalves can promote health risk due to As intoxication as the HQ values were greater than 1.0.The cumulative effect of $\mathrm{HQ}$ of the respective heavy metals was indicated by the value of THI. It was found that the THI values for all species of bivalves were greater than 1.0. The THI value, in decreasing order, of the respective bivalve begins with Pacific oyster (5.07) follows by green-lipped mussel (4.40), marsh clam (1.86) and Asiatic hard clam (1.60).

\subsection{Metal Pollution Index of Bivalves}

Table 5 shows the MPI of bivalves obtained from Marudu Bay. The highest MPI was obtained from Pacific oyster (15.03) followed by green-lipped mussel (8.31), marsh clam (6.86) and Asiatic hard clam (5.79).

\subsection{Principal Component Analysis}

The results of principal component analysis (PCA) of the heavy metals content 
Table 3. Heavy metals content $(\mathrm{mg} / \mathrm{kg})$ in bivalves obtained from Kota Marudu.

\begin{tabular}{|c|c|c|c|c|c|c|c|c|c|c|}
\hline Bivalve & As & $\mathrm{Cd}$ & $\mathrm{Cu}$ & $\mathrm{Fe}$ & $\mathrm{Li}$ & $\mathrm{Mn}$ & $\mathrm{Ni}$ & $\mathrm{Pb}$ & V & $\mathrm{Zn}$ \\
\hline $\begin{array}{c}\text { Asiatic } \\
\text { hard clam }\end{array}$ & $2.40 \pm 0.99$ & b.d.l & $6.57 \pm 9.07$ & $276.5 \pm 230.3$ & $1.12 \pm 0.49$ & $6.92 \pm 4.63$ & $4.92 \pm 2.63$ & $0.90 \pm 1.43$ & $1.11 \pm 0.72$ & $45.25 \pm 19.2$ \\
\hline $\begin{array}{l}\text { Pacific } \\
\text { oyster }\end{array}$ & $5.49 \pm 1.24$ & $2.34 \pm 1.38$ & $74.9 \pm 24.8$ & $285.5 \pm 94.0$ & $3.20 \pm 1.29$ & $20.3 \pm 6.37$ & $4.23 \pm 1.40$ & $2.77 \pm 0.65$ & $3.41 \pm 1.40$ & $822.9 \pm 281.1$ \\
\hline $\begin{array}{l}\text { Marsh } \\
\text { clam }\end{array}$ & $1.95 \pm 0.82$ & $0.24 \pm 0.13$ & $6.42 \pm 1.68$ & $783.0 \pm 284.4$ & $2.16 \pm 0.48$ & $66.1 \pm 77.1$ & $2.58 \pm 3.41$ & $0.95 \pm 0.30$ & $2.09 \pm 0.49$ & $135.5 \pm 53.6$ \\
\hline $\begin{array}{c}\text { Green-lippe } \\
\mathrm{d} \text { mussel }\end{array}$ & $5.72 \pm 1.88$ & $2.72 \pm 1.53$ & $11.29 \pm 17.2$ & $313.6 \pm 216.8$ & $6.76 \pm 9.27$ & $28.81 \pm 19.9$ & $3.10 \pm 2.47$ & $0.56 \pm 1.06$ & $2.23 \pm 1.79$ & $37.92 \pm 13.2$ \\
\hline $\begin{array}{l}\text { Safe limit } \\
(\mathrm{mg} / \mathrm{kg})\end{array}$ & $1.0^{(1)}$ & $3.0^{(2)}$ & $30.0^{(1)}$ & n.a & n.a & $5.4^{(3)}$ & $75^{(2)}$ & $1.0^{(2)}$ & n.a & $100^{(1)}$ \\
\hline $\begin{array}{c}\mathrm{Rfd} \\
(\mathrm{mg} / \mathrm{kg} / \text { day })\end{array}$ & 0.0003 & 0.001 & 0.04 & n.a & n.a & 0.033 & 0.02 & 0.004 & 0.009 & 0.30 \\
\hline
\end{tabular}

Note: b.d.l = below detection limit, Rfd = oral reference dose (USEPA IRIS, 2006), n.a = value not available, 1) MFR (1985), 2) EU (2002), 3) FAO/WHO (1984).

Table 4. HQ and THI of heavy metals in bivalves.

\begin{tabular}{ccccccccccccc}
\hline Bivalve & $\mathrm{As}$ & $\mathrm{Cd}$ & $\mathrm{Cu}$ & $\mathrm{Fe}$ & $\mathrm{Li}$ & $\mathrm{Mn}$ & $\mathrm{Ni}$ & $\mathrm{Pb}$ & $\mathrm{V}$ & $\mathrm{Zn}$ & $\mathrm{THI}$ \\
\hline Asiatic hard clam & $\mathbf{1 . 4 9}$ & n.a & 0.03 & n.a & n.a & 0.04 & 0.05 & 0.04 & 0.02 & 0.03 & 1.60 \\
Pacific oyster & $\mathbf{3 . 4 1}$ & 0.44 & 0.35 & n.a & n.a & 0.11 & 0.04 & 0.13 & 0.07 & 0.51 & $\mathbf{5 . 0 7}$ \\
Marsh clam & $\mathbf{1 . 2 1}$ & 0.04 & 0.03 & n.a & n.a & 0.37 & 0.02 & 0.04 & 0.04 & 0.08 & 1.86 \\
Green mussel & $\mathbf{3 . 5 6}$ & 0.51 & 0.05 & n.a & n.a & 0.16 & 0.03 & 0.03 & 0.05 & 0.02 & $\mathbf{4 . 4 0}$ \\
\hline
\end{tabular}

Note: $\mathrm{n} . \mathrm{a}=$ value not available. Values of HQ greater than 1.0 are highlighted in bold indicating presence of adverse health effect associated with respective heavy metal.

Table 5. Metal pollution indexes of bivalves obtained from Marudu Bay.

\begin{tabular}{cccc}
\hline Bivalve & MPI & Index Value & Degree of Pollution \\
\hline Asiatic hard clam & 5.79 & $5<\mathrm{MPI}<10$ & Low contamination \\
Pacific oyster & 15.03 & $10<\mathrm{MPI}<20$ & Medium contamination \\
Marsh clam & 6.86 & $5<\mathrm{MPI}<10$ & Low contamination \\
Green-lipped mussel & 8.31 & $5<\mathrm{MPI}<10$ & Low contamination \\
\hline
\end{tabular}

in the four bivalve species are illustrated in Table 6. It showed that heavy metals reduced into four factors with the total variation explained of $35.1 \%, 18.2 \%$, 17.2\% and 10.8\% for Factor 1, Factor 2, Factor 3 and Factor 4, respectively. Strong positive correlations were observed between 1) metals $\mathrm{As}, \mathrm{Cd}, \mathrm{Cu}, \mathrm{Pb}, \mathrm{V}$ and $\mathrm{Zn}$ with Factor 1;2) Fe and Mn with Factor 2; 3) Cd and Li with Factor 3 and 4) Ni with Factor 4. On the other hand, opposite correlations were noticed between a) Fe and Mn with Factor 1; b) As, Cd and Li with Factor 2; c) Cu, Ni, $\mathrm{Pb}$ and $\mathrm{Zn}$ with Factor 3, and d) $\mathrm{Cu}, \mathrm{Mn}$ and $\mathrm{Zn}$ with Factor 4. 
Table 6. Principal component analysis: Varimax rotated component matrix.

\begin{tabular}{ccccc}
\hline & Factor 1 & Factor 2 & Factor 3 & Factor 4 \\
\hline $\mathrm{As}$ & 0.75 & -0.03 & 0.48 & 0.13 \\
$\mathrm{Cd}$ & 0.71 & -0.14 & 0.60 & 0.00 \\
$\mathrm{Cu}$ & $\mathbf{0 . 8 2}$ & 0.00 & -0.26 & -0.39 \\
$\mathrm{Fe}$ & -0.28 & $\mathbf{0 . 9 0}$ & 0.13 & 0.04 \\
$\mathrm{Li}$ & 0.20 & -0.19 & $\mathbf{0 . 7 2}$ & 0.09 \\
$\mathrm{Mn}$ & -0.15 & $\mathbf{0 . 8 6}$ & 0.30 & -0.15 \\
$\mathrm{Ni}$ & 0.25 & 0.05 & -0.39 & $\mathbf{0 . 7 9}$ \\
$\mathrm{Pb}$ & $\mathbf{0 . 7 2}$ & 0.20 & -0.41 & 0.04 \\
$\mathrm{~V}$ & $\mathbf{0 . 7 0}$ & 0.36 & 0.04 & 0.35 \\
$\mathrm{Zn}$ & $\mathbf{0 . 7 7}$ & 0.16 & -0.35 & -0.37 \\
Total Variation Explained (\%) & 35.1 & 18.0 & 17.2 & 10.8 \\
\hline
\end{tabular}

\section{Discussion}

\subsection{Heavy Metal Content in Bivalves}

Bivalves are known to have the ability to accumulate great level of heavy metals in their body [16]. This makes them good candidates for bio-indicator to assess the level of metal pollutants in an aquatic system. However, the contents of heavy metals in bivalves are affected by numerous factors. It was noted that intrinsic factors such as species, age, size, metabolic demand, spawning process [17] [18] [19] [20] and extrinsic factors such as type of heavy metals, location and various environmental factors [1] [17] [20] can affect the heavy metal content in bivalves. Many human activities (Table 7 and Table 8) and natural sources such as rocks weathering, runoff of mineralized rocks and hydrological conditions are known to contribute to heavy metals load in the aquatic environment [18]. In the present study, we observed that surface runoff [21], domestic wastewater [22] and boating activities [23] [24] may contribute to the heavy metals deposition in the bay and caused the As and Mn contents in the bivalves to exceed the permissible limits (Table 3).

\subsection{Health Risk Assessment}

Although the As and Mn contents in all analyzed species exceeding the permissible limits, only the HQ value of As was greater than 1.0, which indicates presence of adverse health effects due to As intoxication. The HQ value is not only attributed to the extent of heavy metal content in the food, but also influenced by the exposure frequency as well as the ingestion rate of the contaminated food [25]. Furthermore, the differences in oral reference dose of the respective metal may also affect the HQ value. Upon consumption, the bio-accumulated heavy metals in bivalves body can eventually transferred to human [26] [27]. Inhalation and dermal contact are other recognized routes of heavy metal exposure [28] in human. As reviewed elsewhere [29] [30] [31] [32], heavy metals and 
Table 7. Source(s) and effect(s) of heavy metals for As, Cd, Cr, Cu, Fe, Li and Ni.

\begin{tabular}{|c|c|c|c|}
\hline $\begin{array}{l}\text { Heavy } \\
\text { metal }\end{array}$ & Sources & Effect(s) to human health & References \\
\hline As & $\begin{array}{l}\text { Weathering of natural mineral, } \\
\text { production of paints, dyes and } \\
\text { soaps, arsenical pesticides and } \\
\text { fertilizers. }\end{array}$ & $\begin{array}{l}\text { Lungs, liver, bladder and skin } \\
\text { cancer, cardiovascular disease, } \\
\text { neurological problems, diabetes } \\
\text { mellitus, reduced erythrocyte and } \\
\text { leucocyte production, } \\
\text { hypertension, nausea and } \\
\text { vomiting, skin lesion } \\
\text { (pigmentation and keratosis). }\end{array}$ & {$[40]$} \\
\hline $\mathrm{Cd}$ & $\begin{array}{l}\text { Production of } \mathrm{Cu}, \mathrm{Pb} \text { and } \mathrm{Zn} \text {, } \\
\text { production of alkaline batteries } \\
\text { and electrode components, } \\
\text { production of pigments, plastic } \\
\text { stabilizers, fertilizers. }\end{array}$ & $\begin{array}{l}\text { Kidney and skeletal damage, } \\
\text { disturbance in } \mathrm{Zn} \text { metabolism, } \\
\text { reduced haemoglobin and } \\
\text { haematocrit concentration, } \\
\text { stomach irritation, } \\
\text { vomiting and diarrhea. }\end{array}$ & [34] [40] [54] \\
\hline $\mathrm{Cu}$ & $\begin{array}{l}\text { Fossil fuel combustion, mining } \\
\text { activities, smelting and } \\
\text { refining process of copper, } \\
\text { industry of copper-based } \\
\text { material. }\end{array}$ & $\begin{array}{l}\text { Kidney and liver damage, anaemia, } \\
\text { gastrointestinal problems. }\end{array}$ & [55] \\
\hline $\mathrm{Fe}$ & $\begin{array}{l}\text { Mining activities, } \\
\text { weathering process. }\end{array}$ & $\begin{array}{c}\text { DNA damage, } \\
\text { gastrointestinal problems. }\end{array}$ & {$[40][56]$} \\
\hline $\mathrm{Li}$ & $\begin{array}{l}\text { Ceramic and glass industry, } \\
\text { production of aluminium } \\
\text { and batteries, production of } \\
\text { pharmaceutical drugs. }\end{array}$ & Kidney failure. & {$[57][58]$} \\
\hline $\mathrm{Ni}$ & $\begin{array}{l}\text { Oil spillage, combustion of } \\
\text { coal and fuel oil, steel industry, } \\
\text { forest fire, rocks weathering. }\end{array}$ & $\begin{array}{l}\text { Various kinds of cancer, various } \\
\text { respiratory problems, heart } \\
\text { disorders, birth defects. }\end{array}$ & [54] [59] \\
\hline
\end{tabular}

Table 8. Source(s) and effect(s) of heavy metals $\mathrm{Mn}, \mathrm{Pb}, \mathrm{Sr}, \mathrm{V}$ and $\mathrm{Zn}$.

\begin{tabular}{|c|c|c|c|}
\hline $\begin{array}{l}\text { Heavy } \\
\text { metal }\end{array}$ & Sources & Effect(s) to human health & References \\
\hline $\mathrm{Mn}$ & $\begin{array}{l}\text { Rocks weathering, } \\
\text { wastewater discharges. }\end{array}$ & $\begin{array}{l}\text { Disturbances in circulatory system, } \\
\text { brain damage, promote tumour } \\
\text { development, hypotension, and } \\
\text { retard foetus development. }\end{array}$ & [56] \\
\hline $\mathrm{Pb}$ & $\begin{array}{l}\text { Production of batteries, } \\
\text { smelting and metal plating } \\
\text { process, exhaust from } \\
\text { vehicles, pigment additives, } \\
\text { gasoline, fertilizers and } \\
\text { herbicides. }\end{array}$ & $\begin{array}{l}\text { Brain and kidney damage, hypertension, } \\
\text { arthritis, mental retardation, birth defects, } \\
\text { autism, hyperactivity, psychosis, dyslexia, } \\
\text { hallucinations, insomnia, dizziness, } \\
\text { muscular weakness, fatigue, allergies, } \\
\text { headache, appetite loss, weight loss. }\end{array}$ & {$[40]$} \\
\hline $\mathrm{V}$ & $\begin{array}{l}\text { Weathering of earth crust, } \\
\text { volcanic emissions, } \\
\text { metallurgical works, crude } \\
\text { oil and coal burning. }\end{array}$ & $\begin{array}{l}\text { Potent inhibitor of many enzymes and } \\
\text { cholesterol biosynthesis, reduce plasma } \\
\text { cholesterol level, respiratory irritation. }\end{array}$ & {$[59][60]$} \\
\hline $\mathrm{Zn}$ & $\begin{array}{l}\text { Mining activities, smelting } \\
\text { process, steel production, } \\
\text { coal burning. }\end{array}$ & $\begin{array}{l}\text { Nausea, vomiting, epigastric pain, } \\
\text { lethargy, and fatigue. }\end{array}$ & {$[61]$} \\
\hline
\end{tabular}


metalloids have been reported to cause disturbances at cellular level especially in 1) promoting oxidative stress due to the initiation of reactive oxygen species (ROS), 2) causing DNA damage and impair its repair mechanisms, 3) hindering normal function of cell membrane and the assimilation of nutrient and 4) promoting malfunction of proteins. Moreover, most metals are known to form covalent bonds with carbon and resulting in metal-organic compounds which then interfering the normal functions of various organ systems [33].

\subsubsection{Arsenic}

Arsenic is one of the most toxic heavy metals that extensively studied and reviewed regularly by the international bodies [34]. The immediate effects of acute As intoxication including vomiting, abdominal pain and diarrhea. These symptoms are often followed by numbness, muscle cramps and may also lead to death, in extreme cases [35]. Other than that, it can cause skin cancers and various skin problems, suppress the erythrocyte and leucocyte production and hypertension (Table 7). The possible sources of As in the environment could be originated from mineral weathering, arsenic-based pesticides and fertilizers as well as production of paints, dyes and soap (Table 7). In case of Marudu bay, the leaching of fertilizers residue may promote the accumulation of As in the analyzed bivalves at the extent where it exceeds the permissible limit. Subsequently, presenting the risk of As intoxication to human consumers.

\subsubsection{Copper}

Copper is an essential metal required in various metabolic activities and is well regulated not only in the human body [36] but also in plants [37]. However, prolonged exposure of $\mathrm{Cu}$ above tolerable limit may lead to kidney and liver failure, anaemia and gastrointestinal problems (Table 7). According to [38], $\mathrm{Cu}$ could be accumulated in Marudu Bay because it receives inputs from river discharge and surface runoff from the surrounding areas. In the current study, $\mathrm{Cu}$ content in Pacific oyster harvested from Marudu Bay has exceeded safe level. Human consuming excessive amount of Pacific oyster may primarily be exposed to adverse health effects of $\mathrm{Cu}$ intoxication. Fang and colleagues [39] noticed that oysters ( $C$. rivularis) accumulate higher level of $\mathrm{Cu}$ compared to green mussel ( $P$. viridis) and clam (Ruditapes philippinarum).

\subsubsection{Lead}

The lead content in Pacific oysters originating from the bay was found greater than the permissible limit. Among the known toxic effects of $\mathrm{Pb}$ to human, include brain and kidney damage, muscular weakness, hypertension and arthritis (Table 8). Lead also causes mental retardation and birth defects especially to vulnerable populations such as children and pregnant women [40]. $\mathrm{Pb}$ is a non-essential metal and considered hazardous to human and animals even at low level. The possible sources of $\mathrm{Pb}$ in Marudu Bay include residues of fertilizers and herbicides from oil palm plantation and gasoline from fishing boats [5] [6] [41] [42]. 


\subsubsection{Manganese}

Kota Marudu holds a history of being a former Mn mining area in the late 1903 [43]. Aris and colleagues [41] claimed that metal dispersion, including Mn, might come from the former railway that has been damaged several times during heavy flooding. Other than that, discharge from various domestic wastes is one of the main contributors of $\mathrm{Mn}$ in the aquatic system [44]. The suitability of usage of several rivers in Kota Marudu have been doubted by [41] due to high level of contamination from domestic waste discharge. Although $\mathrm{Mn}$ is an essential enzyme activator [45], exposure to high level of $\mathrm{Mn}$, however, disturbs the central nervous system, causes tumor, hypotension and affects fetus development. The content of $\mathrm{Mn}$ in all analyzed bivalves were exceeding the permissible limits and may promote potential health risk if frequently consumed despite HQ value was below than 1.0.

\subsubsection{Zinc}

In marine environment, $\mathrm{Zn}$ could be attributed to the weathering process or various human activities such as mining, smelting process, steel production and coal or forest burning (Table 8). As an essential metal, $\mathrm{Zn}$ responsible for the normal function of various enzymatic activities and promoting wound healing [45]. However, excess intake or exposure to $\mathrm{Zn}$ can cause nausea, vomiting, abdominal pain, lethargy and fatigue. In the present study, we noticed that the content of $\mathrm{Zn}$ in Pacific oyster and marsh clam were exceeding the permissible limits. Studies have shown that oysters have the ability to accumulate many heavy metals [46]. Meanwhile, marsh clam has been reported to capable of accumulating the highest level of heavy metals among 13 species of clams collected from 34 sites on the Malaysian coasts [47].

\subsection{Metal Pollution Index}

Metal Pollution Index (MPI) is used to identify the extent of heavy metal pollution [48] either in non-biota or biota. According to [25], variation in MPI values noted in different species of organisms is attributed to the differences in feeding habits. However, variation in MPI can also be influenced by season [48].

In the present study, it was shown that Pacific oyster exposed to medium contamination while the other species were categorized under low contamination. Previous study has reported that, oyster $C$. virginica, was unable to eliminate accumulated metals from their soft tissue even after depuration [49]. This condition is attributed to the presence of metallothionein, a cysteine-rich protein that has high affinity to heavy metals [50] which accumulate inside the cells in a non-toxic form [49]. Metallothioneins are responsible in the homeostasis of essential metals ( $\mathrm{Zn}$ and $\mathrm{Cu}$ ), detoxification of toxic metals (especially $\mathrm{Cd}$ ) as well in scavenging free radicals [51]. They were known to be rapidly induced in the liver by a wide range of metals, drugs and inflammatory mediators [52].

\subsection{Principal Component Analysis}

Principal Component Analysis (PCA) was applied in order to highlight the rela- 
tionship among the heavy metals. Metal elements belong to the same groups are usually considered to be originated from the same source [53]. In the present study, $\mathrm{As}, \mathrm{Cd}, \mathrm{Cu}, \mathrm{Pb}, \mathrm{V}$ and $\mathrm{Zn}$ which are dominant variables on Factor 1, are likely to be originated from fertilizers, pesticides and herbicides [5] [6] [41] [42]. These substances are known to be used extensively in oil palm plantation. Leaching of heavy metals from contaminated soil may also occur during surface runoff. Moreover, despite various possible sources of $\mathrm{Fe}$ and $\mathrm{Mn}$, both metals could have been originated from the same source of weathering process or from the domestic wastewater discharge. This was evident in current study where Mn and Fe were grouped together under Factor 2. $\mathrm{Cd}$ and $\mathrm{Li}$ were dominant variables on Factor 3. These elements can be naturally found in rocks minerals, thus weathering process as well as the sand dredging activities which have been reported to have taken place in some rivers flowing into the Marudu Bay [41] may contribute to such finding. Last but not least, oil residue from fishing boats, residues from forest burning during land clearing for agricultural purposes within and in the vicinity areas of study site could have been responsible for the dominance of $\mathrm{Ni}$ in Factor 4.

\subsection{Reducing Health Risk of Heavy Metal in Bivalves}

Water is crucial for the longevity of aquatic organisms. Despite its importance, it receives various environmental threats originating from agricultural activities, effluents from industries and households, and others [62] [63]. Upon the discharge of these wastes, heavy metals and other contaminants are loaded into the aquatic environment. Consequently, these heavy metals will be accumulated in the marine organisms, especially in bivalves following their exposure. This situation can harm human because those metals and other contaminants can be transferred to human through food chain.

Heavy metal contamination can be overcome or removed by mean of bioremediation [64]. It involves the use of living organisms such as algae, bacteria or plants to convert or reduce heavy metals into less toxic forms. The application of microbial bio-sorption to remove or recover heavy metals from aquatic environment has been reviewed by [65]. Risk of heavy metal intoxication and infection of various pathogens arising from the consumption of bivalves can also be reduced by mean of depuration [66]. Depuration is a process whereby bivalves are immersed in clean water environment for a certain period of time to allow purging of biological contaminants and physical impurities from them. El-Gamal [67] noticed that $\mathrm{Zn}, \mathrm{Pb}, \mathrm{Ni}, \mathrm{Mn}, \mathrm{Cu}, \mathrm{Cr}$ and $\mathrm{Cd}$ can be reduced by $44 \%, 23 \%, 25 \%, 17 \%, 61 \%, 41 \%$ and $75 \%$ in clam, Paphia undulata after immersion in clean artificial seawater for 24 hours, respectively. The same author also showed that depuration process reduced the presence of Vibrio sp. (75\%), Shigella sp. (31\%), Escherichia coli (68\%) and Salmonella sp. (36\%) in the clam. Subjecting the newly caught bivalves to depuration process for more than 24 hours in clean water environment before consumption will help reduce health 
risk from contaminants including heavy metals.

Besides, strict enforcement of environmental law and policies in the bivalve natural habitat also help keep them away from being exposed to heavy metal contaminants. In Malaysia, the Ministry of Natural Resources and Environment has recognized the important of public participation in the effort to mitigate environmental pollution by providing an online complaint service for public to report any environmental polluting activities occurring in their surroundings [68].

\section{Conclusion}

The present study has shown that the levels of As and $\mathrm{Mn}$ in the four bivalve species originating from Marudu Bay exceeded the permissible limits. It also found that Pacific oyster in the bay seemed to experience medium heavy metal contamination while the green-lipped mussel, marsh clam and Asiatic hard clam were subjected to low level of heavy metal contamination. Overall, the current study suggests that consumption of bivalves originating from Marudu Bay at high frequency could elevate the risk of heavy metal intoxication particularly from Asernic. Although, thorough analysis is still required, there is already a convincing evident that presence of heavy metals in Marudu Bay is likely to be escalating in the future due to the intense anthropogenic activities. As a step to reduce health risk from heavy metal intoxication associated with bivalve consumption, environmental laws and policies related to wastewater discharge into the aquatic system particularly the natural habitat for bivalve should be strictly enforced, zones for bivalve fisheries should be established, monitoring metals concentration in bivalve on regular basis and last but not least is to make depuration a compulsory requirement in every seafood restaurant.

\section{Acknowledgements}

This study was financially supported by a research funding (NRGS0003) from the Ministry of Higher Education (MOHE), Malaysia.

\section{References}

[1] Sharif, R., Chong, E. and Chan, K.M. (2016) Human Health Risk Assessment of Heavy Metals in Shellfish from Kudat, Sabah. Malaysian Journal of Nutrition, 22, 301-305.

[2] Jamil, T., Lias, K., Norsila, D and Syafinaz, N.S. (2014) Assessment of Heavy Metal Contamination in Squid (Loligo Spp.) Tissues of Kedah-Perlis Waters, Malaysia. The Malaysian Journal of Analytical Sciences, 18, 195-203.

[3] Yuswir, N.S., Praveena, S.M., Aris, A.Z., Ismail, S.N.S. and Hashim, Z. (2015) Health Risk Assessment of Heavy Metal in Urban Surface Soil (Klang District, Malaysia). Bulletin of Environmental Contamination and Toxicology, 95, 80. https://doi.org/10.1007/s00128-015-1544-2

[4] Budin, K., Praveena, S.M., Sakari, M., Hassan, S. and Ibrahim, E.I. (2014) Health Risk Assessment of Heavy Metals via Consumption of Bivalves Species in Kota Ki- 
nabalu, Sabah, Malaysia. In: Aris, T.I., Harun, A. and Ishak, Eds., From Sources to Solution, Springer Singapore, Singapore, 585-590.

[5] Zakaria, M. and Rajpar, M.N. (2015) Assessing the Fauna Diversity of Marudu Bay Mangrove Forest, Sabah, Malaysia, For Future Conservation. Diversity, 7, 137-148. https://doi.org/10.3390/d7020137

[6] Denil, D.J., Ransangan, J., Tan, K.S. and Ching, F.F. (2017) Seasonal Variation of Heavy Metals (Cu, Mn, Ni and $\mathrm{Zn}$ ) In Farmed Green Mussel (Pernaviridis) In Marudu Bay, Sabah, Malaysia. International Journal of Aquatic Science, 8, 51-60.

[7] FAO/WHO (1984) List of Maximum Levels Recommended for Contaminants by the Joint FAO/ WHO Codex Alimentarius Commission. Second Series. CAC/FAL, Rome, 3, 1-8.

[8] Soon, T.K., Denil, D.J. and Ransangan, J. (2016) Temporal and Spatial Variability of Heavy Metals in Marudu Bay, Malaysia. Oceanological and Hydrobiological Studies, 45, 353-367. https://doi.org/10.1515/ohs-2016-0032

[9] de Carvalho, G.P., Cavalcante, P.R.S., de Castro ,A.C.L. and Rojas, M.O.A.I. (2000) Preliminary Assessment of Heavy Metal Levels in Mytela falcate (Bivalvia, Mytilidae) from Bacaga River Estuary, São Luis, State Of Maranhão, Northeastern Brazil. RevistaBrasileira de Biologia, 60, 11-16. https://doi.org/10.1590/S0034-71082000000100003

[10] Yap, C.K., Hatta, Y., Edward, F.B. and Tan, S.G. (2008) Comparison of Heavy Metal Concentrations (Cd, Cu, Fe, Ni And $\mathrm{Zn}$ ) in the Shells and Different Soft Tissues of Anadaragranosa Collected from Jeram, Kuala Juru And Kuala Kurau, Peninsular Malaysia. Pertanika Journal of Tropical Agricultural Science, 31, 205-208.

[11] Taweel, A., Shuhaimi-Othman, M. and Ahmad, A.K. (2013) Assessment of Heavy Metals in Tilapia Fish (Oreochromisniloticus) from the Langat River and Engineering Lake in Bangi, Malaysia, and Evaluation of the Health Risk from Tilapia Consumption. Ecotoxicological and Environmental Safety, 93, 45-51.

[12] Maigari, A.U., Ekanem, E.O., Garba, I.H., Harami, A. and Akan, J.C. (2016) Health Risk Assessment for Exposure to Some Selected Heavy Metals via Drinking Water from Dadinkowa Dam and River Gomber Abba in Gomber State, Northeast Nigeria. World Journal of Analytical Chemistry, 4, 1-5.

[13] FAO (1989) A Regional Survey of the Aquaculture Sector in West Asia. Document Prepared by Pathak, S.C. United Nation Development Programme. FAO, Rome.

[14] Azmi, M.Y., Junidah, R., Siti Mariam, A., Safiah, M.Y., Fatimah, S., Morimah, A.K., Poh, B.K., Kandiah, M., Zalilah, M.S., Wan Abdul Manan, W.M., SitiHaslinda, M.D. and Tahir, A. (2009) Body Mass Index (BMI) of Adults: Findings of the Malaysian Adults Nutrition Survey (MANS). Malaysian Journal of Nutrition, 15, 97-119.

[15] Usero, J., González-Regalado, E. and Gracia, I. (1997) Trace Metals in the Bivalve Molluscs Ruditapes decussatus and Ruditapesphilippinarus from the Atlantic Coast of Southern Spain. Environment International, 23, 291-298.

[16] Oliveira, G.F.M., Couto, M.C.M.D., Lima, M.D.F. and Bomfim, T.C.B.D. (2016) Mussels (Perna Perna) as Bioindicator of Environmental Contamination by Cryptospodium Species with Zoonotic Potential. International Journal for Parasitology: Parasites and Wildlife, 5, 28-33.

[17] Abdullah Mohd, H., Sidi, J. and Aris Ahmad, Z. (2007) Heavy Metal (Cd, Cu, Cr, Pb and $\mathrm{Zn}$ ) in Meretrixmeretrix Roding, Water and Sediments from Estuaries in Sabah, North Borneo. International Journal of Environmental and Science Education, 2, 69-74. 
[18] Amisah, S., Adjei-Boateng, D., Obirikorang, K.A. and Quagrainie, K.K. (2009) Effects of Clam Size on Heavy Metal Accumulation in Soft Tissues of Galatea Paradoxa (Born, 1778) from Volta Estuary, Ghana. International Journal of Fisheries and Aquaculture, 1, 14-21.

[19] Rzymski, P., Niedzielski, P., Klimaszyk, P. and Poniedzialek, B. (2014) Bioaccumulation of Selected Metals in Bivalves (Unionidae) and Phragmitesaustralis Inhabiting a Municipal Water Reservoir. Environmental Monitoring and Assessment, 186, 3199-3212. https://doi.org/10.1007/s10661-013-3610-8

[20] Swaleh, M.M., Ruwa, R., Wainaina, M.N., Ojwang, L.M., Shikuku, S.L. and Maghanga, J.K. (2016) Heavy Metals Bioaccumulation in Edible Marine Bivalve Mollusks of Tudor Creek Mombasa Kenya. Journal of Environmental Science, Toxicology and Food Technology, 10, 42-52. https://doi.org/10.9790/2402-1008024352

[21] Pereira, E., Baptista-Neto, J.A., Smith, B.J. and McAllister, J.J. (2007) The Contribution of Heavy Metal Pollution Derived from Highway Runoff to Guanabara Bay Sediments-Rio de Janeiro/Brazil. Annals of the Brazilian Academy of Sciences, 74, 739-750. https://doi.org/10.1590/S0001-37652007000400013

[22] Comber, S.D.W. and Gunn, A.M. (1996) Heavy Metals Entering Sewage-Treatment Works from Domestic Sources. Water and Environment Journal, 10, 137-142. https://doi.org/10.1111/j.1747-6593.1996.tb00023.x

[23] Goh, B.P.I. and Chou, L.M. (1997) Heavy Metal Levels in Marine Sediments of Singapore. Environmental Monitoring and Assessment, 44, 67-80. https://doi.org/10.1023/A:1005763918958

[24] Al-Mur, B.A., Quicksall, A.N. and Al-Ansari, A.M.A. (2017) Spatial and Temporal Distribution of Heavy Metals in Coastal Core Sediments from the Red Sea, Saudi Arabia. Oceanologia, 59, 262-270.

[25] Ahdy, H.H.H., Abdallah, A.M.A. and Tayel, F.T. (2007) Assessment of Heavy Metals and Nonessential Content of Some Edible and Soft Tissues. Egyptian Journal of Aquatic Research, 33, 85-97.

[26] Monachese, M., Burton, J.P. and Reld, G. (2012) Bioremediation and Tolerance of Humans to Heavy Metals through Microbial Processes: A Potential Role for Probiotic? Applied and Environmental Microbiology, 78, 6397-6404. https://doi.org/10.1128/AEM.01665-12

[27] Gall, J.E., Boyd, R.S. and Rajakaruna, N. (2015) Transfer of Heavy Metals through Terrestrial Food Webs: A Review. Environmental Monitoring and Assessment, 187, 201. https://doi.org/10.1007/s10661-015-4436-3

[28] Mamtani, R., Stern, P., Dawood, I. and Cheema, S. (2011) Metals and Disease: A Global Primary Health Care Perspective. Journal of Toxicology, 2011, Article ID: 319136. https://doi.org/10.1155/2011/319136

[29] Beyersmann, D. and Hartwig, A. (2008) Carcinogenic Metal Compounds: Recent Insight into Molecular and Cellular Mechanisms. Archives of Toxicology, 82, 493-512. https://doi.org/10.1007/s00204-008-0313-y

[30] Wysocki, R. and Tamas, M.J. (2010) How Saccharomyces cerevisiae Copes with Toxic Metals and Metalloids. FEMS Microbiology Reviews, 34, 925-951. https://doi.org/10.1111/j.1574-6976.2010.00217.x

[31] Lemire, J.A., Harrison, J.J and Turner, R.J. (2013) Antimicrobial Activity of Metals: Mechanisms, Molecular Targets and Application. Microbiology, 11, 371-384. https://doi.org/10.1038/nrmicro3028

[32] Tamas, M.J., Sharma, S.K., Ibstedt, S., Jacobson, T. and Christen, P. (2014) Heavy 
Metals and Metalloids as a Cause for Protein Misfolding and Aggregation. Biomolecules, 4, 252-267. https://doi.org/10.3390/biom4010252

[33] Flora, S.J.S. and Pichauri, V. (2010) Chelation in Metal Intoxication. International Journal of Environmental Research and Public Health, 7, 2745-2788. https://doi.org/10.3390/ijerph7072745

[34] Jarup, L. (2003) Hazards of Heavy Metal Contamination. British Medical Bulletin, 68, 167-182. https://doi.org/10.1093/bmb/ldg032

[35] WHO (2016) Arsenic. Fact Sheet. http://www.who.int/mediacentre/factsheets/fs372/en/

[36] Angelova, M., Asenova, S., Nedkova, V. and Koleva-Kolarova, R. (2011) Copper in the Human Organism. Trakia Journal of Sciences, 9, 88-98.

[37] Yruela, I. (2005) Copper in Plants. Brazilian Journal of Plant Physiology, 17, 145-156. https://doi.org/10.1590/S1677-04202005000100012

[38] Asamudin, A.H. and Mohamed, C.A.R. (2011) Distribution of Trace Elements and Total Organic Carbon in Surface Sediments of the Sulu and Sulawesi Seas. Journal of Tropical Marine Ecosystem, 2, 22-29.

[39] Fang, Z.Q., Cheung, Y.H. and Wong, M.H. (2003) Heavy Metals in Oysters, Mussels and Clams Collected from Coastal Sited along the Pearl River Delta, South China. Journal of Environmental Sciences, 15, 9-24.

[40] Jaishankar, M., Tseten, T., Anbalagan, N., Mathew, B.B. and Beeregowda, K.N. (2014) Toxicity, Mechanism and Health Effects of Some Heavy Metals. Interdisciplinary Toxicology, 7, 60-72. https://doi.org/10.2478/intox-2014-0009

[41] Aris, A.Z., Lim, W.Y., Praveena, M., Ramli, M.F. and Juahir, H. (2014) Water Quality Status of Selected Rivers in Kota Marudu, Sabah, Malaysia and Its Suitability for Usage. Sains Malaysiana, 43, 377-388.

[42] Hanum, I.F., Abd Kudus, K. and Saari, N.S. (2012) Plant Diversity and Biomass of Marudu Bay Mangroves in Malaysia. Pakistan Journal of Botany, 44, 151-156.

[43] Stephens, E.A. (1956) The Geology and Mineral Resources of Part of the Kota Belud and Kudat Area North Borneo. Geological Survey Department, British Territories in Borneo, Memoir 5.

[44] Howe, P., Malcolm, H. and Dobson, S. (2004) Manganese and Its Compounds: Environmental Aspects. World Health Organization, Geneva.

[45] FAO (1987) The Nutrition and Feeding of Farmed Fish ANS Shrimp-A Training Manual 1. The Essential Nutrients. Document Prepared by Tacon, A.G.J. Government Cooperative Programme. FAO, Brazil.

[46] Shazili, N.A.M., Yunus, K., Ahmad, A.S., Abdullah, N. and Rashid, M.K.A. (2006) Heavy Metal Pollution Status in the Malaysian Aquatic Environment. Aquatic Ecosystem Health and Management, 9, 137-145. https://doi.org/10.1080/14634980600724023

[47] Hossen, M.F., Hamdan, S. and Rahman, M.R. (2015) Review on the Risk Assessment of Heavy Metals in Malaysian Clams. The Scientific World Journal, 2015, Article ID: 905497.

[48] Omar, W.A., Mikhail, W.Z.A., Abdo, H.M., El Defan, T.A.A and Poraas, M.M. (2015) Ecological Risk Assessment of Metal Pollution along Greater Cairo Sector of the River Nile, Egypt, using Nile Tilapia, Oreochromisniloticus, as Bioindicator. Journal of Toxicology, 2015, Article ID: 167319.

https://doi.org/10.1155/2015/167319 
[49] Guzman-Garcia, X., Botello, A.V., Martinez-Tabche, L. and Gonzales-Marquez, H. (2009) Effects of Heavy Metals on the Oyster (Crassostrea virginica) at Mandinga Lagoon, Veracruz, Mexico. Revista de Biologia Tropical, 57, 955-962.

[50] Shirneshan, G. and Bakhtiari, A.R. (2012) Accumulation and Distribution of Cd, $\mathrm{Cu}, \mathrm{Pb}$ and $\mathrm{Zn}$ in the Soft Tissue and Shell of Oysters Collected from the Northern Coast of Qeshm Island, Persian Gulf, Iran. Chemical Speciation and Bioavailability, 24, 129-138. https://doi.org/10.3184/095422912X13394368814321

[51] Isani, G. and Carpene, E. (2014) Metallothioneins, Unconventional Proteins from Unconventional Animals: A Long Journey from Nematodes to Mammals. Biomolecules, 4, 435-457. https://doi.org/10.3390/biom4020435

[52] Coyle, P., Philcox, J.C., Carey, L.C. and Rofe, A.M. (2002) Metallothioneins: The Multipurpose Protein. Cellular and Molecular Life Sciences, 59, 627-647.

https://doi.org/10.1007/s00018-002-8454-2

[53] Nemr, A.E., Khaled, A., Moneer, A.A. and Sikaly, A.E. (2012) Risk Probability Due to Heavy Metals in Bivalve from Egyptian Mediterranean Coast. Egyptian Journal of Aquatic Research, 38, 67-75.

[54] Dinis, M.D.L. and Fiúza, A. (2011) Exposure Assessment to Heavy Metals in the Environment: Measures to Eliminate or Reduce the Exposure to Critical Receptors. In: Simeonov, L., Kochubovski, M. and Simeonova, B., Eds., Environmental Heavy Metal Pollution and Effects on Child Mental Development, NATO Science for Peace and Security Series C: Environmental Security, Vol. 1. Springer, Dordrecht. https://doi.org/10.1007/978-94-007-0253-0_2

[55] DES (2013) Copper: Health Information Summary. New Hampshire Department of Environmental Services, New Hampshire.

[56] Javed, M. and Usmani, N. (2013) Assessment of Heavy Metal (Cu, Ni, Fe, Co, Mn, $\mathrm{Cr}, \mathrm{Zn}$ ) Pollution in Effluent Dominated Rivulet Water and Their Effect on Glycogen Metabolism and Histology of Mastacembalusarmatus. Springerplus, 2, 390. https://doi.org/10.1186/2193-1801-2-390

[57] Kszos, L.A. and Stewart, A.J. (2003) Review of Lithium in the Aquatic Environment: Distribution in the United States, Toxicity and Case Example of Groundwater Contamination. Ecotoxicology, 12, 439-447. https://doi.org/10.1023/A:1026112507664

[58] Timmer, R.T. and Sands, J.M. (1999) Lithium Intoxification. Journal of the American Society of Nephrology, 10, 666-674.

[59] Haidari, B., Bakhtiari, A.R., Yavari, V., Kazemi, A. and Shirneshan, G. (2013) Biomonitoring of $\mathrm{Ni}$ and $\mathrm{V}$ Contamination using Oysters (Saccostreacucullata) at Lengeh Port, Persian Gulf, Iran. Clean-Soil, Air, Water, 41, 166-173.

https://doi.org/10.1002/clen.201100564

[60] WHO (2000) Air Quality Guidelines for Europe. 2nd Edition, WHO Regional Publication, European Series, No. 91, Copenhagen.

[61] Fosmire, G.J. (1990) Zinc Toxicity. American Journal of Clinical Nutrition, 51, 225-227.

[62] Asubiojo, O.I. and Ajelabi, O.B. (2009) Removal of Heavy Metals from Industrial Wastewaters Using Natural Adsorbents. Toxicological and Environmental Chemistry, 91, 883-890. https://doi.org/10.1080/02772240802614721

[63] Yao, H., Qian, X., Gao, H., Wang, Y. and Xia, B. (2014) Seasonal and Spatial Variations of Heavy Metals in Two Typical Chinese Rivers: Concentrations, Environmental Risks and Possible Sources. International Journal of Environmental Research and Public Health, 11, 11860-11878. 
https://doi.org/10.3390/ijerph111111860

[64] Rajendran, P., Muthukrishnan, J. and Gunasekaran, P. (2003) Microbes in Heavy Metal Remediation. Indian Journal of Experimental Biology, 41, 935-944.

[65] Ayangbenro, A.S. and Babaloba, O.O. (2017) A New Strategy for Heavy Metal Polluted Environment: A Review of Microbial Biosorbents. International Journal of Environmental Research and Public Health, 14, 94. https://doi.org/10.3390/ijerph14010094

[66] FAO (2008) Bivalve Depuration: Fundamental and Practical Aspects. Document Prepared by Lee, R., Lovatelli, A. and Ababouch, L. Fisheries Technical Paper. FAO, Rome.

[67] El-Gamal, M.M. (2011) The Effect of Depuration on Heavy Metals, Petroleum Hydrocarbons and Microbial Contamination Levels in Paphiaundulata (Bivalvia: Veneridae). Czech Journal of Animal Science, 56, 345-354.

[68] Department of Environment, Ministry of Natural Resources \& Environment (2017) Complaint and Enquiry. https://www.doe.gov.my/portalv1/en/aduan-pertanyaan 